\title{
Impact of Neutral Amino Acids and Sodium Dodecyl Sulphate on Ripening of Kashkaval Cheese
}

\author{
El-Safty, M. S., A. M. Abou El-Nour, Amira M. El-Kholy, R. A. M. Khalil and Safaa M. Mokbel \\ Dairy Department, Faculty of Agriculture, Suez Canal University, Ismailia 41522, Egypt
}

Received: $25 / 10 / 2020$

\begin{abstract}
The aim of the present study was to evaluate the impact of neutral amino acid and sodium dodecyl sulphate (SDS) on maturity of Kashkaval cheese. Results indicated that adding neutral amino acids and SDS to Kashkaval cheese curd improved the rheological and sensory properties significantly and had a good apprecuated effect on cheese quality. Using mixture of asparagines and leucine increased moisture, F/DM, TN, salt/moisture, acidity, WSN, WSN/TN, TVFA, FAA and springiness while decreased $\mathrm{pH}$, hardness, cohesiveness, gumminess and chewiness. Kashkaval cheese supplemented with mixture of the neutral amino acids asparagine and leucine $(1 \mathrm{mg}$ asparagine +1 $\mathrm{mg}$ leucine/Kg curd) was considered to be superior to the control or other experimental cheese followed by cheese supplemented with $2 \mathrm{mg}$ leucine/Kg curd. Furthermore, it achieved the best results for the rheological characteristics.
\end{abstract}

Keywords: Kashkaval cheese, neutral amino acid, cheese ripening

\section{INTRODUCTION}

Since proteolysis is a slow process and may be a limiting factor in ripening, methods to accelerate proteolysis have attracted much interest in the recent years (Fox et al., 1996). One of these methods is adding amino acids which in turn act as precursors for flavourforming reactions to produce $\mathrm{NH}_{3}$, amines, aldehydes, acids and alcohols which gave the specific flavor for each type of cheese (Gripon et al., 1991). Flavour, texture and appearance of cheese depend basically on protein breakdown process which called proteolysis. Adding amino acids has been used to accelerate cheese proteolysis. There are only very few reports on the effects of adding amino acids to cheese curd during manufacture on the rate of flavour development. ElSafty et al. $\left(1983_{\mathrm{a}}\right)$, stated that addition of acidic amino acids mixture improved Ras cheese flavour, but caused hardness of cheese body, while neutral amino acids mixture had a pronounced effect on improving the cheese flavour and its consistency. Basic amino acids mixture had a negligible effect on cheese flavour. They found that addition of different amino acids mixture accelerated cheese ripening. Meanwhile, El-Safty et al. (1989), studied the effect of adding different percentages of a mixture of acidic amino acids (asparatic acid + glutamic acid 1:1) to Ras cheese curd. The results showed that such addition of encouraged protein breakdown, accelerated cheese ripening and improved the cheese flavour but caused hardness for cheese body. Addition of disodium hydrogen phosphate with acidic amino acids mixture improved the cheese consistency. On the other hand, acidic amino acid mixture had a pronounced effect on the organoleptic properties of Domiati cheese made from reconstituted milk than the basic amino acid mixture (El-Safty et al., $1983_{\mathrm{b}}$ ). The addition of acidic and basic amino acids mixtures accelerated Domiati cheese ripening. Wallace and Fox (1997), supplemented Cheddar cheeses with cas-amino acids (0-63 $\left.\mathrm{mmol} \mathrm{kg}^{-1}\right)$ during manufacture. They stated that Cheeses with intermediate levels of added amino acids developed a flavour and texture superior to either the controls or the cheeses with highest contents of cas-amino acids after a 6-month of ripening period.

Felicio et al. (2016), stated that sodium chloride reduction by potassium chloride $(0,25$ and $50 \%)$ and addition of arginine $(1 \% \mathrm{w} / \mathrm{w})$ to Minas cheese represented a possibility of developing a product with good flavour and reduced sodium content.

Another method to accelerate cheese ripening is using sodium dodecyl sulphate (SDS). Depending on its ability to open the closed structure of protein and dissociate protein to its subunits (Fox, 1982). So, it can be used to accelerate the cheese ripening. Metwally and Nasr (1989) indicated that the addition of $0.05 \%$ SDS could be successfully used in the acceleration of Edam cheese ripening. Nasr and Metwally (1989), studied the addition of SDS to Romi cheese for accelerating the ripening. They reported that the addition of $0.05 \%$ SDS enhanced the growth of starter microorganisms in Romi cheese and improved the organoleptic properties. Moreover the partially effect of SDS $(0.05 \%)$ on the dissociation of protein was most suitable for giving Romi cheese with highly acceptable score. Also, Farag et al. (1992) concluded that the addition of SDS alone or in combination with lipase enhanced the development of texture and flavour in Blue cheese and improved Penicilliurn roqueforti distribution throughout the cheese. Cheese treated with SDS $(0.075 \%)$ combined with lipase greatly enhanced the development of flavour characteristics and improved body and texture and overall cheese quality.

Kashkaval is a semi-hard, yellow cheese that derives its name from the Italian cheese "Caciocavallo". The term Caciocavallo is used to describe a semi hard pasta filata cheese historically produced in various Italian regions (Succi et al., 2016). Different types of Caciocavallo cheeses can be produced with different manufacturing technologies, varying the kind of milk used and its thermal treatment, the use of starter culture and its composition, and the curd and cheese ripening conditions, leading to products characterized by different traits (Niro et al., 2014). 
The objective of this investigation was to study the impact of the addition of neutral amino acid and sodium dodecyl sulphate (SDS) on maturity of kashkaval cheese and to evaluate the chemical, rheological and sensory properties of cheese during the ripening period.

\section{MATERIALS AND METHODS}

\section{Materials:}

Fresh Cow's and buffalo's milk were obtained from the herd of Faculty of Agriculture, Suez Canal University, Ismailia governorate. Yoghurt culture containing Streptococcus thermophiles and Lactobacillus delbrueckii spp. bulgaricus (DVS) was obtained from Chr-Hansen's laboratories, Denmark. Rennet powder, CHY-MAX was obtained from ChrHansen's laboratories, Denmark. Commercial salt was obtained from the local market. Amino acids, sodium dodecyl sulphate and calcium chloride were obtained from El-Naser pharmaceutical and chemical company, Cairo governorate, Egypt.

\section{Experimental procedure:}

Five treatments were carried out. All treatments were made from mixture of buffalo's and cow's milk (1:1) standardized to $3.3 \%$ fat, $11.8 \%$ TS, $2.63 \%$ casein and $0.8 \mathrm{C} / \mathrm{F}$. Treatment 1 (T1) serves as full fat control Kashkaval cheese. Treatment 2 (T2) was made by adding $2 \mathrm{mg}$ asparagine/Kg curd, Treatment 3(T3) was made by adding $2 \mathrm{mg}$ leucine $/ \mathrm{Kg}$ curd, Treatment 4 (T4) was made by adding mix of $1 \mathrm{mg}$ asparagine +1 $\mathrm{mg}$ leucine/Kg curd while, Treatment 5 (T5) was made by adding $0.075 \%$ sodium dodecyl sulphate (SDS) to the cheese curd. Kashkaval cheese was manufactured as described by Simov and Ivanov (2005) as shown in Fig. (1). The resultant cheese was stored for 45 days at $10^{\circ} \mathrm{C}$ and $80 \%$ relative humidity. The whole experiment was thrice.

\section{Methods of analysis:}

Analysis of cheese milk (Total solids, Fat and Casein content) was carried out according to the methods described in AOAC (2007). Cheese samples were analyzed chemically when fresh and after 15, 30 and 45 days of ripening. Moisture content, water soluble nitrogen (WSN) and total nitrogen content (TN) were measured by Kjeldahl method using semi-micro Kjeldahl according to the methods described by AOAC (2007). Acidity was determined by the titration method according to Vujicic et al. (1996). $\mathrm{pH}$ value was measured by using (Jenway digital $\mathrm{pH}$ meter, Jenway Limited, England). Salt content was determined according to Volhard method and fat content by Gerber butyrometer as described by Ling (1963). Free amino acids value (expressed as Absorbance at $507 \mathrm{~nm} / 100 \mu 1$ WSN) was estimating using cadmium-ninhydrin method as described by Folkertsma and Fox (1990). Total volatile fatty acids contents (TVFA) were estimated by the distillation method according to Kosikowski (1982). Values were expressed as $\mathrm{ml}$ of $0.1 \mathrm{~N} \mathrm{NaOH} / 100 \mathrm{gm}$ cheese.

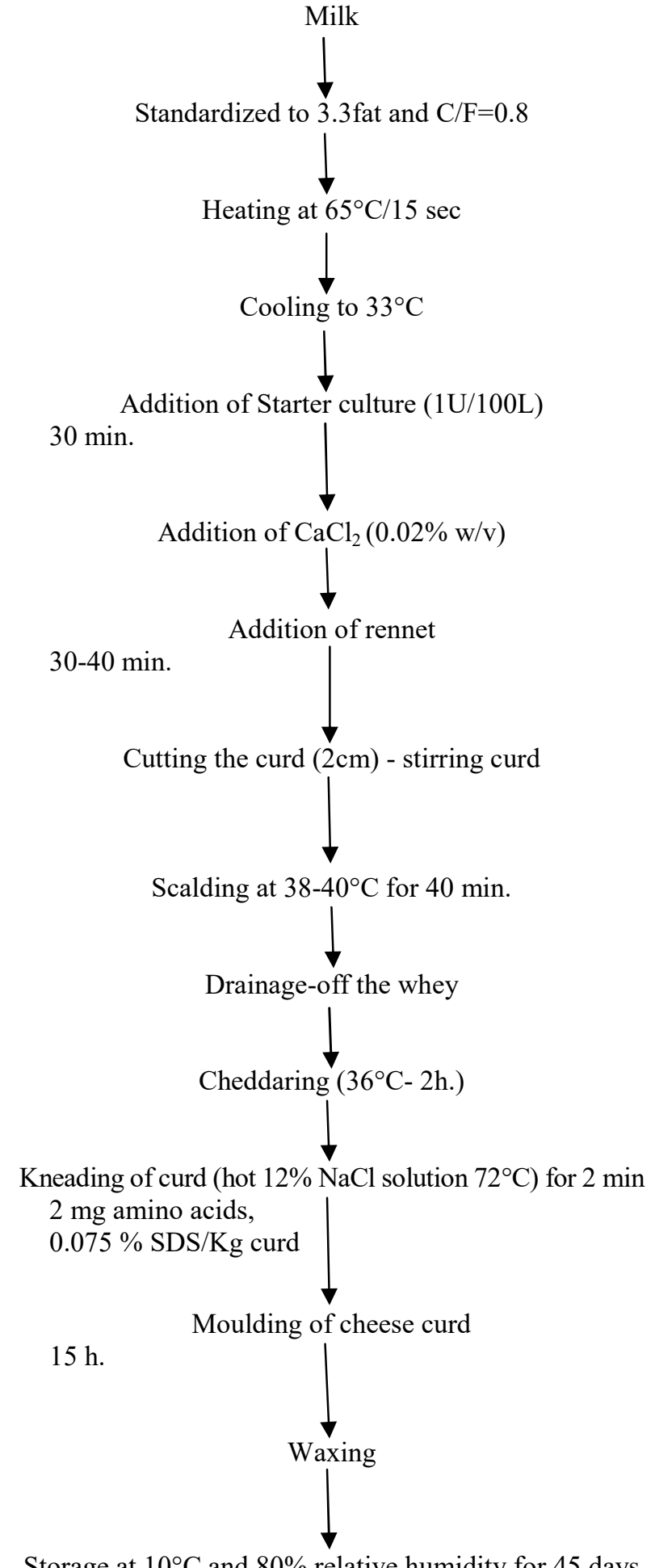

Storage at $10^{\circ} \mathrm{C}$ and $80 \%$ relative humidity for 45 days

Fig. (1): Flow sheet of Kashkaval cheese manufacture.

\section{Rheological properties:}

Texture profile analysis test of cheese samples (which shape was $2 \times 2 \times 2$ clyndrical) was done using a Universal Testing Machine (TMS-Pro) Food Technology Corporation, Sterling, Verginia, USA) equipped with $1000 \mathrm{~N}$ (250 lbf) load cell and connected to a computer programmed with Texture Pro ${ }^{\mathrm{TM}}$ texture analysis software (program, DEV TPA With holding time between cycle two second). A flat rod probe (49.95 
$\mathrm{mm}$ in diameter) to uniaxially compress the "cheese samples with the following parameters conduction to $30 \%$ of their original height. Each sample was subjected to two subsequent cycles (bites) of compressiondecompression. Data were collected on computer and the texture profile parameters were calculated from DEV TPA texture analyzer and computer interface. Calculation described by Szczesniak et al. (1963), Bourne (1978) was used to obtain the following texture profile parameters (Hardness, Cohesiveness, Springiness, Gumminess and Chewiness). The rheological characteristics were determined when fresh, 15 and 45 days of storage.

\section{Sensory evaluation:}

The sensory evaluation of cheese samples was carried out according to the method of Pappas et al. (1996) when fresh and after 15, 30 and 45 days of storage with maximum score points for flavour (50 points), body and texture (40 points) and appearance and colour (10 points). The sensory evaluation was carried out by 15 members of Dairy Department, Faculty of Agriculture, Suez Canal University.

\section{Statistical analysis:}

All measurements were done in triplicate and analysis of variance with two factorial (treatments and storage period) were conducted by the procedure of General Linear Model (GLM) using CoStat (1998) under windows software version 6.311 and least significant differences (LSD) test were employed to determine significant difference at $\mathrm{p}<0.05$.

\section{RESULTS AND DISCUSSION}

\section{Gross Chemical Composition:}

Table (1) shows the averages of moisture contents of Kashkaval cheese treatments. It can be seen that the moisture content of treatment 4 (T4) was higher $(\mathrm{p} \leq 0.05)$ than the other treatments. Felicio et al. (2016) found that adding arginine to Minas cheese increased the moisture content due to the effect of arginine on water holding capacity in the cheese matrix, they also explained that amino acids are able to establish chemical bonds with water and other cheese component. Using SDS in treatment 5 (T5) decreased markedly ( $\mathrm{p} \leq$ 0.05 ) the moisture content of cheese of different ages. In contrast to these results, Nasr and Metwally (1989) reported that using SDS in Romi cheese making had a negligible effect on moisture content. On the other hand, the moisture content of all treatments showed a marked $(p \leq 0.05)$ decrease throughout the storage period. Similar results were also observed by Gobbetti et al. (2002), Santa and Srbinovska (2014).

It can be seen from values given in Table (1), fat on dry matter $(\mathrm{F} / \mathrm{DM})$ increased significantly $(\mathrm{p} \leq 0.05)$ by using neutral amino acids. While, using SDS did not affect F/DM (T5) as compared to control cheese (T1). This was noticed in fresh and during cheese ripening. It was noticed that F/DM content of all treatments increased significantly $(\mathrm{p} \leq 0.05)$ as storage progressed. These variations may be due to the changes in moisture content of different cheese treatments during storage.
Similar results were observed by Santa and Srbinovska (2014).

According to the obtained results (Table 1), total nitrogen content (TN) of treatment 4 (T4) was significantly $(p \leq 0.05)$ higher than the other treatments when fresh and throughout the storage period. The TN values increased significantly $(\mathrm{p} \leq 0.05)$ among all treatments with advanced storage. This increase might be due to loss of moisture content during the storage period. These results are in agreement with Abd ElGawad et al. (2007), Santa and Srbinovska (2014), Talevski et al. (2017). Salt on moisture (S/M\%) increased significantly $(\mathrm{p} \leq 0.05)$ by adding neutral amino acids, while adding SDS decreased remarkably $(\mathrm{p} \leq 0.05)$ the salt on moisture. Treatment 4 (T4) had the highest $(\mathrm{p} \leq 0.05)$ salt/moisture percentage as compared to the other treatments. During the ripening period, salt/moisture increased markedly $(\mathrm{p} \leq 0.05)$ as a result of the decrease in moisture content. These results concur with those reported by Santa and Srbinovska (2014).

The changes in acidity and $\mathrm{pH}$ values of Kashkaval cheese as affected by the applied treatments and during the storage time are presented in Table (1). It was noticed that the titratable acidity increased when neutral amino acids (asparagine- leucine) were used, while there is no significant $(p>0.05)$ differences between treatment 2 (cheese treated with $2 \mathrm{mg}$ asparagines) and 3 (cheese treated with $2 \mathrm{mg}$ leucine). El-Safty et al. (1983a), Abu-El nour (1987) reported the same results with Ras cheese. The titratable acidity of treatment 5 was higher than control (T1). This result may be due to the direct effect of SDS as ionic salt or to the indirect effect of SDS as responsible for the disassociation of casein micelles (Fox, 1982). These results are in agreement with Nasr and Metwally (1989). There are no significant $(\mathrm{p}>0.05)$ differences in $\mathrm{pH}$ values between treatments. Also, it was noticed that there was a continuous increase in acidity and a decrease in $\mathrm{pH}$ values during the storage period for all cheese treatments. These results are in agreement with Santa and Srbinovska (2014).

\section{Ripening indices:}

The water soluble nitrogen (WSN) and water soluble nitrogen coefficient (WSN/TN) increased significantly $(\mathrm{p} \leq 0.05)$ as neutral amino acids and SDS were used (Table 2). Treatment 4 had the highest $(\mathrm{p} \leq$ 0.05 ) value of WSN and water soluble nitrogen coefficient followed by treatment 3 as compared with control cheese and the other treatments. These results are in agreement with Abu-El Nour (1987), Wallace and Fox (1997). The obtained result showed that SDS treated cheese at level $0.075 \%$ had higher values of WSN and WSN/TN than control cheese. These results could be explained on the basis that added SDS denatured and dissociation the protein substrates into their subunits (Fox, 1982).

The WSN and WSN/TN percentages increased significantly $(\mathrm{p} \leq 0.05)$ as storage progressed. Similar results were reported by Niro et al. (2014), Talevski et al. (2017). Concerning the total volatile fatty acids (TVFA), It is clear that the addition of neutral amino 
acids affected significantly $(\mathrm{p} \leq 0.05)$ TVFA content. Abu-El Nour (1987) reported that addition of mixture of acidic amino acids to cheese curd accelerated fat hydrolysis in Ras cheese along the ripening period. Adding SDS increased TVFA values when fresh and during the storage period. This is in agreement with Nasr and Metwally (1989) who found that addition of SDS to Romi cheese increased TVFA values.
Also, Farag et al. (1992) stated that addition of SDS to blue cheese curd enhanced the formation of free fatty acids during ripening. All treatments had a significant $(p \leq 0.05)$ increase values of TVFA during storage period. These results are in agreement with Hassan (2005), Abd El-Gawad et al. (2007). This increament during the storage time may be due in part to the residual activity of heat resistance lipase which may cause the fat hydrolysis (Mansour, 2005).

Table (1): Effect of using neutral amino acids and sodium dodecyl sulphate (SDS) on gross chemical composition of Kashkaval cheese during ripening period (Average of three replicates)

\begin{tabular}{|c|c|c|c|c|c|}
\hline \multirow{3}{*}{ Treatments } & \multicolumn{4}{|c|}{ Storage Period (days) } & \multirow{3}{*}{ Mean } \\
\hline & \multicolumn{4}{|c|}{ Moisture content $(\%)$} & \\
\hline & Fresh & 15 & 30 & 45 & \\
\hline T1 & 45.10 & 43.68 & 43.13 & 42.69 & $43.64^{C}$ \\
\hline $\mathbf{T 2}$ & 45.15 & 43.71 & 43.22 & 42.70 & $43.70^{\mathrm{BC}}$ \\
\hline T3 & 45.23 & 43.75 & 43.29 & 42.75 & $43.76^{\mathrm{B}}$ \\
\hline T4 & 45.35 & 43.82 & 43.32 & 42.82 & $43.83^{\mathrm{A}}$ \\
\hline T5 & 44.9 & 43.55 & 42.97 & 42.50 & $43.52^{\mathrm{D}}$ \\
\hline Mean $^{* * *}$ & $45.15^{\mathrm{a}}$ & $43.70^{b}$ & $43.18^{\mathrm{c}}$ & $42.73^{\mathrm{d}}$ & \\
\hline \multicolumn{6}{|c|}{ *F/DM\% } \\
\hline T1 & 46.08 & 46.52 & 46.95 & 47.11 & $46.67^{\mathrm{D}}$ \\
\hline $\mathbf{T} 2$ & 46.13 & 46.72 & 47.20 & 47.47 & $46.88^{\mathrm{C}}$ \\
\hline T3 & 46.38 & 46.76 & 47.43 & 47.69 & $47.07^{\mathrm{B}}$ \\
\hline T4 & 46.48 & 46.99 & 47.46 & 47.92 & $47.21^{\mathrm{A}}$ \\
\hline T5 & 46.10 & 46.59 & 46.82 & 47.30 & $46.70^{\mathrm{D}}$ \\
\hline Mean $^{* *}$ & $46.23^{\mathrm{d}}$ & $46.72^{\mathrm{c}}$ & $47.17^{\mathrm{b}}$ & $47.50^{\mathrm{a}}$ & \\
\hline \multicolumn{6}{|c|}{$* \mathbf{T N} \%$} \\
\hline T1 & 4.11 & 4.30 & 4.36 & 4.41 & $4.30^{\mathrm{D}}$ \\
\hline $\mathbf{T} 2$ & 4.14 & 4.35 & 4.39 & 4.44 & $4.33^{\mathrm{BC}}$ \\
\hline T3 & 4.15 & 4.38 & 4.42 & 4.46 & $4.35^{\mathrm{B}}$ \\
\hline T4 & 4.17 & 4.41 & 4.45 & 4.49 & $4.38^{\mathrm{A}}$ \\
\hline T5 & 4.12 & 4.32 & 4.37 & 4.43 & $4.31^{\mathrm{CD}}$ \\
\hline Mean $^{* *}$ & $4.14^{\mathrm{d}}$ & $4.35^{\mathrm{c}}$ & $4.40^{\mathrm{b}}$ & $4.45^{\mathrm{a}}$ & \\
\hline \multicolumn{6}{|c|}{ *S/M_\% } \\
\hline T1 & 2.84 & 2.99 & 3.18 & 3.35 & $3.09^{\mathrm{D}}$ \\
\hline $\mathbf{T} 2$ & 2.86 & 3.04 & 3.16 & 3.37 & $3.11^{\mathrm{C}}$ \\
\hline T3 & 2.92 & 3.13 & 3.30 & 3.49 & $3.21^{\mathrm{B}}$ \\
\hline T4 & 2.93 & 3.19 & 3.37 & 3.53 & $3.26^{\mathrm{A}}$ \\
\hline T5 & 2.83 & 2.99 & 3.16 & 3.32 & $3.08^{\mathrm{E}}$ \\
\hline Mean $^{* * *}$ & $2.88^{\mathrm{d}}$ & $3.07^{\mathrm{c}}$ & $3.23^{\mathrm{b}}$ & $3.41^{\mathrm{a}}$ & \\
\hline \multicolumn{6}{|c|}{ Acidity\% } \\
\hline T1 & 0.90 & 1.19 & 1.21 & 1.26 & $1.14^{\mathrm{D}}$ \\
\hline $\mathbf{T} 2$ & 0.92 & 1.23 & 1.27 & 1.32 & $1.19^{\mathrm{B}}$ \\
\hline T3 & 0.95 & 1.24 & 1.27 & 1.33 & $1.20^{\mathrm{B}}$ \\
\hline T4 & 0.95 & 1.26 & 1.29 & 1.36 & $1.22^{\mathrm{A}}$ \\
\hline T5 & 0.92 & 1.21 & 1.23 & 1.29 & $1.16^{\mathrm{C}}$ \\
\hline Mean & $0.93^{\mathrm{d}}$ & $1.23^{\mathrm{c}}$ & $1.25^{\mathrm{b}}$ & $1.31^{\mathrm{a}}$ & \\
\hline \multicolumn{6}{|c|}{ pH } \\
\hline T1 & 5.40 & 5.31 & 5.30 & 5.26 & $5.32^{\mathrm{A}}$ \\
\hline $\mathbf{T} 2$ & 5.36 & 5.29 & 5.27 & 5.24 & $5.29^{\mathrm{AB}}$ \\
\hline T3 & 5.33 & 5.29 & 5.26 & 5.22 & $5.28^{\mathrm{AB}}$ \\
\hline T4 & 5.33 & 5.27 & 5.24 & 5.20 & $5.26^{\mathrm{B}}$ \\
\hline T5 & 5.35 & 5.30 & 5.28 & 5.25 & $5.30^{\mathrm{AB}}$ \\
\hline Mean $^{* *}$ & $5.35^{\mathrm{a}}$ & $5.29^{b}$ & $5.27^{\mathrm{bc}}$ & $5.23^{\mathrm{c}}$ & \\
\hline
\end{tabular}

T1: control, T2: $2 \mathrm{mg}$ asparagine/Kg curd, T3: $2 \mathrm{mg}$ leucine/Kg curd, T4: $1 \mathrm{mg}$ asparagine $+1 \mathrm{mg}$ leucine /Kg curd, T5: $0.075 \%$ SDS. $* \mathrm{~F} / \mathrm{DM}$ : fat on dry matter *TN: total nitrogen *S/M: salt on moisture

**a, b \& c and A, B, C \& D: means with the same letters among treatments and storage period respectively are not significantly different $(\mathrm{p}>0.05)$ 
Table (2): Effect of using neutral amino acids and sodium dodecyl sulphate (SDS) on water soluble nitrogen (WSN \%), water soluble nitrogen coefficient and total volatile fatty Acids (TVFA)* of Kashkaval cheese during storage (Average of three replicates)

\begin{tabular}{|c|c|c|c|c|c|}
\hline \multirow{3}{*}{ Treatments } & \multicolumn{4}{|c|}{ Storage period (days) } & \multirow{3}{*}{ Mean } \\
\hline & Fresh & 15 & 30 & 45 & \\
\hline & \multicolumn{4}{|c|}{ WSN_\% } & \\
\hline T1 & 0.220 & 0.311 & 0.439 & 0.552 & $0.381^{\mathrm{E}}$ \\
\hline $\mathbf{T} 2$ & 0.234 & 0.327 & 0.444 & 0.561 & $0.392^{\mathrm{C}}$ \\
\hline T3 & 0.236 & 0.330 & 0.449 & 0.566 & $0.395^{\mathrm{B}}$ \\
\hline T4 & 0.239 & 0.335 & 0.455 & 0.572 & $0.400^{\mathrm{A}}$ \\
\hline T5 & 0.231 & 0.321 & 0.441 & 0.557 & $0.388^{\mathrm{D}}$ \\
\hline \multirow[t]{2}{*}{ Mean $^{* *}$} & $0.232^{\mathrm{d}}$ & $0.325^{\mathrm{c}}$ & $0.446^{\mathrm{b}}$ & $0.562^{\mathrm{a}}$ & \\
\hline & \multicolumn{4}{|c|}{ WSN/TN\% } & \\
\hline T1 & 5.35 & 7.23 & 10.07 & 12.52 & $8.79^{\mathrm{E}}$ \\
\hline $\mathbf{T} 2$ & 5.65 & 7.51 & 10.11 & 12.64 & $8.98^{C}$ \\
\hline T3 & 5.69 & 7.53 & 10.16 & 12.69 & $9.02^{\mathrm{B}}$ \\
\hline T4 & 5.73 & 7.59 & 10.22 & 12.74 & $9.07^{\mathrm{A}}$ \\
\hline T5 & 5.61 & 7.43 & 10.09 & 12.57 & $8.93^{\mathrm{D}}$ \\
\hline \multirow[t]{2}{*}{ Mean $^{* * *}$} & $5.61^{\mathrm{d}}$ & $7.46^{\mathrm{c}}$ & $10.13^{\mathrm{b}}$ & $12.63^{\mathrm{a}}$ & \\
\hline & \multicolumn{4}{|c|}{ *TVFA } & \\
\hline T1 & 2.6 & 5.8 & 8.2 & 8.6 & $6.3^{\mathrm{E}}$ \\
\hline $\mathbf{T} 2$ & 2.6 & 6.5 & 8.5 & 9.0 & $6.7^{\mathrm{C}}$ \\
\hline T3 & 2.7 & 6.7 & 8.9 & 9.3 & $6.9^{\mathrm{B}}$ \\
\hline T4 & 2.7 & 7.0 & 9.5 & 9.8 & $7.3^{\mathrm{A}}$ \\
\hline T5 & 2.6 & 6.0 & 8.3 & 8.7 & $6.4^{\mathrm{D}}$ \\
\hline Mean $^{* * *}$ & $2.6^{\mathrm{d}}$ & $6.4^{\mathrm{c}}$ & $8.7^{\mathrm{b}}$ & $9.1^{\mathrm{a}}$ & \\
\hline
\end{tabular}

See Table (1) for treatments designation

*TVFA expressed as ml $0.1 \mathrm{~N} \mathrm{NaOH} / 100 \mathrm{~g}$ cheese.

$* * a, b, c \& d$ and A, B, C, D \& E: means with the same letters among treatments and storage period respectively are not significantly different $(p>0.05)$

\section{Free Amino Acids formation (FAA):}

The evolution of free amino acids (FAA) of Kashkaval cheese as affected by neutral amino acids and SDS is shown in Table (3). Adding neutral amino acids increased the absorbance values of FAA significantly $(p \leq 0.05)$. Wallace and Fox (1997) found the same results for Cheddar cheese. Also using SDS increased FAA significantly $(\mathrm{p} \leq 0.05)$ as compared with the control cheese (T1). This may be due to the effect of SDS on the dissociation of casein into their subunits (Fox 1982). Kashkaval cheese made with adding mixture of neutral amino acids (T4) gave the highest $(p \leq 0.05)$ values of FAA followed by cheese made using leucine (T3) whereas control cheese had the lowest ( $\mathrm{p} \leq$ 0.05 ) concentration of FAA. These results are consistent with the results of WSN prementioned in cheese from treatments (T4 and T3). Concentration of free amino acid increased pronouncedly $(\mathrm{p} \leq 0.05)$ during storage. These results are consistent with the determination of WSN, which increased in all cheese throughout ripening period.

Table (3): Changes in free amino acids (expressed as A507) during ripening of Kashkaval cheese as affected by using neutral amino acids and sodium dodecyl sulphate (SDS) (Average of three replicates)

\begin{tabular}{llllll}
\hline \multirow{2}{*}{ Treatments } & \multicolumn{2}{c}{ Storage period (days) } & \multicolumn{2}{c}{ Mean } \\
\cline { 2 - 6 } T1 & Fresh & $\mathbf{1 5}$ & $\mathbf{3 0}$ & $\mathbf{4 5}$ & 0.166 \\
T2 & 0.017 & 0.059 & 0.93 & 0.175 & $0.092^{\mathrm{C}}$ \\
T3 & 0.024 & 0.065 & 0.104 & 0.193 & $0.103^{\mathrm{B}}$ \\
T4 & 0.027 & 0.073 & 0.118 & 0.219 & $0.130^{\mathrm{A}}$ \\
T5 & 0.051 & 0.101 & 0.147 & 0.171 & $0.089^{\mathrm{D}}$ \\
\hline Mean & 0.023 & 0.061 & 0.102 & $\mathbf{0 . 1 8 5}^{\mathbf{a}}$ &
\end{tabular}

See Table (1) for treatments designation

$* * a, b, c \& d$ and A, B, C, D \& E: means with the same letters among treatments and storage period respectively are not significantly different $(p>0.05)$ 


\section{Rheological Characteristics:}

Cheese rheology can be described as the study of cheese deformation and flow under stress or strain. This behavior related to the cheese composition, microstructure and macrostructure (Fox et al., 2017).

\section{Hardness:}

Fox et al. (2000), defined hardness as high resistance to deformation by applied stress. Data presented in Table (4) indicated that adding neutral amino acids decreased the hardness significantly $(\mathrm{p} \leq$ 0.05 ). The highest and the lowest hardness values were related to $\mathrm{T} 1$ and $\mathrm{T} 4$ respectively. Adding SDS in treatment 5 decreased the hardness markedly $(\mathrm{p} \leq 0.05)$ as compared to control cheese (T1). During the storage period, the hardness of all cheese samples increased pronouncedly $(p \leq 0.05)$ up to the day 15 and then decreased at the end of the ripening. The hardness related to the moisture content so, when the moisture decreased the hardness increased. The decrease in hardness at the end of the storage period is related to cheese proteolysis. The increase in hardness during ripening might a result from the reduction in the level of free water, which increases cheese resistance to deformation (Beal. and Mittal, 2000).

Table (4): Effect of using neutral amino acids and sodium dodecyl sulphate (SDS) on hardness, Springiness and Cohesiveness of Kashkaval cheese during ripening periods (Average of three replicates)

\begin{tabular}{|c|c|c|c|c|}
\hline \multirow{3}{*}{ Treatments } & \multicolumn{3}{|c|}{ Storage Period (days) } & \multirow{3}{*}{ Mean } \\
\hline & Fresh & 15 & 45 & \\
\hline & \multicolumn{3}{|c|}{ Hardness (N) } & \\
\hline T1 & 18.8 & 33.3 & 23.40 & $25.17^{\mathrm{A}}$ \\
\hline $\mathbf{T} 2$ & 18.0 & 32.5 & 22.70 & $24.4^{\mathrm{C}}$ \\
\hline T3 & 17.6 & 32.0 & 22.60 & $24.07^{\mathrm{D}}$ \\
\hline $\mathbf{T 4}$ & 17.1 & 31.2 & 22.00 & $23.43^{\mathrm{E}}$ \\
\hline T5 & 18.2 & 32.87 & 23.10 & $24.72^{\mathrm{B}}$ \\
\hline Mean $^{* *}$ & $17.94^{\mathrm{c}}$ & $32.37^{\mathrm{a}}$ & $22.76^{\mathrm{b}}$ & \\
\hline \multicolumn{5}{|c|}{ Springiness (mm) } \\
\hline T1 & 4.25 & 1.95 & 1.68 & $2.63^{\mathrm{E}}$ \\
\hline $\mathbf{T} 2$ & 4.39 & 2.00 & 1.77 & $2.72^{\mathrm{C}}$ \\
\hline T3 & 4.48 & 2.02 & 1.80 & $2.77^{\mathrm{B}}$ \\
\hline T4 & 4.51 & 2.15 & 1.93 & $2.86^{\mathrm{A}}$ \\
\hline T5 & 4.33 & 1.98 & 1.74 & $2.68^{\mathrm{D}}$ \\
\hline Mean $^{* *}$ & $4.39^{\mathrm{a}}$ & $2.02^{\mathrm{b}}$ & $1.78^{\mathrm{c}}$ & \\
\hline \multicolumn{5}{|c|}{ Cohesiveness (Ratio) } \\
\hline T1 & 0.69 & 0.86 & 0.72 & $0.76^{\mathrm{A}}$ \\
\hline $\mathbf{T} 2$ & 0.65 & 0.82 & 0.68 & $0.72^{\mathrm{C}}$ \\
\hline T3 & 0.64 & 0.80 & 0.66 & $0.70^{\mathrm{D}}$ \\
\hline T4 & 0.54 & 0.73 & 0.59 & $0.62^{\mathrm{E}}$ \\
\hline T5 & 0.67 & 0.84 & 0.70 & $0.74^{\mathrm{B}}$ \\
\hline Mean $^{* * *}$ & $0.64^{\mathrm{c}}$ & $0.81^{\mathrm{a}}$ & $0.67^{\mathrm{b}}$ & \\
\hline
\end{tabular}

See Table (1) for treatments designation

$* * a, b$ \&,$c$ and A, B, C, D \& E: means with the same letters among treatments and storage period respectively are not significantly different $(\mathrm{p}>0.05)$

\section{Springiness and Cohesiveness:}

Springiness defined as rate at which deformed food returns to original condition after removal force (Tunick, 1999; Fox et al., 2000). It can be noticed that the control kashkaval cheese (T1) had the lowest ( $\mathrm{p} \leq$ $0.05)$ springiness value among all treatments, while treatment 4 had the highest $(\mathrm{p} \leq 0.05)$ springiness value (Table 4). This may be related to the hardness values. Adding neutral amino acids and SDS increased markedly $(p \leq 0.05)$ springiness values compared to control (T1). In all treatments springiness values decreased remarkably $(\mathrm{p} \leq 0.05)$ during the ripening period. This may be due to the breakdown of protein matrix which dependent on some factors such as moisture and fat content of cheese (El-Zeini et al., 2007).
Cohesiveness, measures of tendency of cheese to remain together and resist breaking into several pieces, during compression (Fox et al., 2017). It is clear that treatment (T4) had the lowest $(\mathrm{p} \leq 0.05)$ value of cohesiveness while treatment $(\mathrm{T} 1)$ had the highest $(\mathrm{p} \leq$ $0.05)$ value. Adding neutral amino acids and SDS decreased $(\mathrm{p} \leq 0.05)$ the cohesiveness. During ripening periods, the cohesiveness increased up to 15 days then decreased by the end of ripening. Proteolysis disrupts the structural integrity of the protein matrix, leading to reduced cohesiveness (Beal and Mittal, 2000). Proteolysis was higher in the less cohesive cheeses.

\section{Gumminess and Chewiness:}

Gumminess defined as force needed to disintegrate a semisolid food to a state ready for Swallowing (Tunick, 1999). Control Kashkaval cheese (T1) had the highest $(\mathrm{p} \leq 0.05)$ value of gumminess than 
the other treatments while, treatment 4 had the lowest $(\mathrm{p} \leq 0.05)$ value (Table 5). This may be due to the high hardness value of treatment (T1) and the lowest $(p<0.05)$ hardness value of treatment 4 (T4). Adding neutral amino acids and SDS decreased significantly $(\mathrm{p} \leq 0.05)$ the gumminess of Kashkaval cheese. This may be due to the reduction of hardness by adding neutral amino acids and SDS. Gumminess of all treatments increased significantly $(\mathrm{p} \leq 0.05)$ up to 15 days and then decreased significantly at the end of ripening period.

In terms of chewiness, it can be noticed from Table (5) that the chewiness values of treatment (T1) was higher $(p \leq 0.05)$ than those of the other treatments. This may be due to the higher hardness value of treatment (T1). On the other hand (T4) exhibit the lowest $(p \leq 0.05)$ chewiness value compared to other treatments. This result may be due to the lowest hardness value of treatment (T4). Adding neutral amino acids and SDS decreased the chewiness of Kashkaval cheese. This may be due to the reduction of hardness by adding neutral amino acids and SDS.

As chewiness, work needed to masticate a solid food to a state ready for swallowing (Tunick, 1999). There is a correlation between hardness and chewiness, harder cheese is more difficult to chew (Beal and Mittal, 2000). Chewiness of all treatments increased significantly $(\mathrm{p} \leq 0.05)$ up to 15 days and then decreased significantly at the end of ripening period.

Table (5): Effect of using neutral amino acids and sodium dodecyl sulphate (SDS) on the Gumminess and Chewiness of Kashkaval cheese during ripening periods (Average of three replicates)

\begin{tabular}{lcccc}
\hline & \multicolumn{3}{c}{ Storage Period (days) } & Mean \\
\cline { 2 - 4 } Treatments & Fresh & $\mathbf{1 5}$ & $\mathbf{4 5}$ & $19.49^{\mathrm{A}}$ \\
\cline { 2 - 4 } T1 & 12.97 & Gumminess (N) & 16.85 & $17.93^{\mathrm{C}}$ \\
T2 & 11.70 & 28.64 & 15.44 & $17.26^{\mathrm{D}}$ \\
T3 & 11.26 & 26.65 & 14.92 & $14.99^{\mathrm{E}}$ \\
T4 & 9.23 & 25.6 & 12.98 & $18.66^{\mathrm{B}}$ \\
T5 & 12.19 & 22.78 & 16.17 & \\
Mean & $11.47^{\mathrm{c}}$ & 27.61 & $15.27^{\mathrm{b}}$ & \\
\hline & & $26.26^{\mathrm{a}}$ & $46.43^{\mathrm{A}}$ \\
\hline T1 & 55.12 & Chewiness (N) & 28.31 & $44.00^{\mathrm{C}}$ \\
T2 & 51.36 & 55.85 & 27.33 & $43.00^{\mathrm{D}}$ \\
T3 & 50.44 & 53.30 & 26.86 & $38.55^{\mathrm{E}}$ \\
T4 & 41.63 & 51.70 & 25.05 & $45.20^{\mathrm{B}}$ \\
T5 & 52.78 & 48.98 & 28.14 & $27.14^{\mathrm{c}}$ \\
Mean & $50.27^{\text {b }}$ & 54.67 & $52.90^{\mathrm{a}}$ &
\end{tabular}

See Table (1) for treatments designation

$* * a, b \& c$ and A, B, C, D \& E: means with the same letters among treatments and storage period respectively are not significantly different $(\mathrm{p}>0.05)$

\section{Sensory evaluation:}

The addition of neutral amino acids and SDS to kashkaval cheese improved the flavour, the body \& texture and overall acceptability. These results are in accordance with Nasr and Metwally (1989), Wallace and Fox (1997). As shown in Table (6), treatment 4 gained the highest $(\mathrm{p} \leq 0.05)$ score points for falvour, body \&texture, and overall acceptability either when fresh or during storage period. Same results were reported by Felicio et al. (2016) who found that the addition of arginine positively affected probiotic Minas cheese flavour. In general for all cheeses total score points were higher for 45 days old cheeses as compared with fresh cheeses. It is well known that degradation of casein improves both texture and flavour. It was noticed that treatment 4 which has a mixture of asparagine and leucine gained the highest $(\mathrm{p} \leq 0.05)$ score for all sensory properties among all treatments when fresh and throughout storage period. Addition of mixture of neutral amino acids (asparagine and leucine) to kashkaval cheese curd enhanced the development of flavour characteristics and improved body and texture more than all the other treatments. These results could be attributed to the increased accumulation of nitrogenous compounds and total free fatty acids and formation of carbonyl compounds (Farag et al., 1992).

From the above results it could be concluded that adding neutral amino acids and SDS to kashkaval cheese curd improved the sensory and rheological properties significantly and had a good apprecuated effect on cheese quality. The cheese supplemented with mixture of the neutral amino acids asparagine and leucine ( $1 \mathrm{mg}$ asparagine $+1 \mathrm{mg}$ leucine $/ \mathrm{Kg}$ curd) was considered by the graders to be superior to the control or other experimental cheese followed by cheese supplemented with $2 \mathrm{mg}$ leucine/Kg curd. 
Table (6): Effect of using neutral amino acids and sodium dodecyl sulphate (SDS) on the organoleptic properties of Kashkaval cheese during ripening periods

\begin{tabular}{|c|c|c|c|c|c|}
\hline \multirow{3}{*}{ Treatment } & \multicolumn{4}{|c|}{ Storage period (days) } & \multirow{3}{*}{ Mean } \\
\hline & Fresh & 15 & 30 & 45 & \\
\hline & \multicolumn{4}{|c|}{ Flavour (50 points) } & \\
\hline T1 & 29 & 33 & 43 & 46 & $37.8^{\mathrm{D}}$ \\
\hline $\mathbf{T 2}$ & 30 & 35 & 44 & 46 & $38.8^{\mathrm{C}}$ \\
\hline T3 & 33 & 37 & 46 & 47 & $40.8^{\mathrm{B}}$ \\
\hline T4 & 36 & 40 & 47 & 49 & $43.0^{\mathrm{A}}$ \\
\hline T5 & 30 & 34 & 44 & 45 & $38.3^{\mathrm{CD}}$ \\
\hline Mean $^{* *}$ & $31.6^{\mathrm{d}}$ & $35.8^{\mathrm{c}}$ & $44.8^{\mathrm{b}}$ & $46.6^{\mathrm{a}}$ & \\
\hline \multicolumn{6}{|c|}{ Body \& Texture (40 points) } \\
\hline T1 & 25 & 28 & 32 & 35 & $30.0^{\mathrm{C}}$ \\
\hline $\mathbf{T} 2$ & 26 & 30 & 34 & 37 & $31.8^{\mathrm{b}}$ \\
\hline T3 & 26 & 30 & 35 & 37 & $32.0^{\mathrm{B}}$ \\
\hline T4 & 26 & 32 & 37 & 39 & $33.5^{\mathrm{A}}$ \\
\hline T5 & 26 & 29 & 34 & 37 & $31.5^{\mathrm{B}}$ \\
\hline Mean** & $25.8^{\mathrm{d}}$ & $29.8^{\mathrm{c}}$ & $34.4^{\mathrm{b}}$ & $37.0^{\mathrm{a}}$ & \\
\hline \multicolumn{6}{|c|}{ Appearance and colour (10 points) } \\
\hline T1 & 8 & 8 & 9 & 9.5 & $8.6^{\mathrm{A}}$ \\
\hline $\mathbf{T 2}$ & 8 & 8 & 9 & 9.5 & $8.6^{\mathrm{A}}$ \\
\hline $\mathbf{T 3}$ & 8 & 8 & 9 & 9.5 & $8.6^{\mathrm{A}}$ \\
\hline T4 & 8 & 8 & 9 & 9.5 & $8.6^{\mathrm{A}}$ \\
\hline T5 & 8 & 8 & 9 & 9.5 & $8.6^{\mathrm{A}}$ \\
\hline Mean** & $8.0^{c}$ & $8.0^{\mathrm{c}}$ & $9.0^{\mathrm{b}}$ & $9.5^{\mathrm{a}}$ & \\
\hline \multicolumn{6}{|c|}{ Overall acceptability (100 points) } \\
\hline T1 & 62 & 69 & 84 & 90.5 & $76.4^{\mathrm{E}}$ \\
\hline $\mathbf{T 2}$ & 64 & 73 & 87 & 92.5 & $79.1^{\mathrm{C}}$ \\
\hline T3 & 67 & 75 & 90 & 93.5 & $81.4^{\mathrm{B}}$ \\
\hline T4 & 70 & 80 & 93 & 97.5 & $85.1^{\mathrm{A}}$ \\
\hline T5 & 64 & 71 & 87 & 91.5 & $78.4^{\mathrm{D}}$ \\
\hline Mean** & $65.4^{\mathrm{d}}$ & $73.6^{\mathrm{c}}$ & $88.2^{\mathrm{b}}$ & $93.1^{\mathrm{a}}$ & \\
\hline
\end{tabular}

See Table (1) for treatments designation

**a b b c \& d and A, B, C, D \& E: means with the same letters among treatments and storage period respectively are not significantly different $(p>0.05)$

\section{REFERENCES}

Abd El-Gawad Mona, A. M., A. M. Sabek Reda and A. Hegazi Nagla (2007). Quality and properties of low-fat buffaloe 's kashkaval cheese. International Journal of Dairy Science, 2: 244-251.

Abu El-Nour, A. M. (1987). Studies on acceleration of Ras cheese ripening. M.Sc. Thesis. Suez Canal University, Egypt.

AOAC (2007). Official Methods of Analysis $18^{\text {th }}$ ed., Association of Official Analysis Chemists Inc., USA.

Beal, P. and G. Mittal (2000). Vibration and compression responses of Cheddar cheese at different fat content and age. Milchwissenschaft, 55: 139-142.

Bourne, M. C. (1978). Texture profile analysis. Food Technology, 32: 62-67.
Costat (1998). Users manual for Costat version 6.311. Cohort soft ware; Berkeley; CA.

El-Safty, M. S., A. L. EL-Zayat, A. A. Mohamed and A. M. Abou El-Nour (1989). Effect of acidic amino acids mixture on quality and ripening of Ras cheese. Egyptian Journal of Dairy Science, 17: 115-124.

El-Safty, M. S., A. A. Nofal and A. Hekmat (1983a). The effect of different amino acids mixtures on quality and ripening of Ras cheese made from reconstituted milk. Egyptian Journal of Food Science, 11: 63-71.

El-Safty, M. S., A. A. Nofal and A. Hekmat (1983b). The effect of acidic and basic amino acids mixtures on quality and ripening of Domiati cheese made from reconstituted milk. Egyptian Journal of Food Science, 11: 115122. 
El-Zeini, M. M., M. A. Al-Assar, S. M. K. Anis and E. A. H. Romeih (2007). Influence of some processing treatments on chemical composition, rheological properties and microstructure of Cast UF-white soft cheese. Egyptian Journal of Dairy Science, 35: 57-72.

Farag, A. A., M. E. Aly and M. B. El-Alfy (1992). Enhancement of blue cheese flavor using sodium dodecylsulphate and lipase. Molecular Nutrition Food Research Journal, 36: 1-7.

Felicio, T. L., E. A. Esmerino, V. A. S. Vidal, L. P. Cappato, R. K. A. Garcia, R. N. Cavalcanti, M. Q. Freitas, C. A. Conte Junior, M. C. Padilha, M. C. Silva, R. S. L. Raices, D. B. Arellano, H. M. A. Bollini, M. A. R. Pollonio and A. G. Cruz (2016). Physicochemical changes during storage and sensory acceptance of low sodium probiotic Minas cheese added with arginine. Food Chemistry Journal, 196: 628-637.

Folkertsma, B. and P. F. Fox (1990). Use of the Cdninhydrin reagent to assess proteolysis in cheese during ripening. Journal of Dairy Research, 59: 217-224.

Fox, P. F. (1982). Developments in Dairy Chemistry-1, Protein. P.197. Edited by P.F. Fox, Applied Science Publisher, London.

Fox, P. F., T. P. Guinee, T. M. Cogan and P. L. H. McSweeney (2000). Cheese Rheology and Texture, In Fundamental of Cheese Science, Aspen Publications, USA, pp. 305-324.

Fox, P. F., T. P. Guine, T. M. Cogan and P. L. H. McSweeney (2017). Cheese, Structure, Rheology and Texture in Fundamentals of Cheese Science. $2^{\text {nd }}$ Edition Springer, New York, pp 475-532.

Fox, P. F., J. M. Wallace, S. Morgan, C. M. Lynch, E. J. Niland and J. Tobin (1996). Acceleration of cheese ripening. Antonie van Leeuwenhoek, 70, 271-297.

Gobbetti, M., M. Morea, F. Baruzzi, M. R. Corbo, A. Matarante, T. Considine, R. Di Cagno, T. Guinee and P. F. Fox (2002). Microbiological, compositional, biochemical and textural characterization of caciocavallo pugliese cheese during ripening. International Dairy Journal, 12: 511-523.

Gripon, J. C., V. Monnet, G. Lamberet and M. J. Desmazeaud (1991). Microbial enzymes in cheese ripening. In Food Enzymology, ed. P. F. Fox, Vol. 1, pp. 131-169. Elsevier Applied Science, London.

Hassan, S. A. M. (2005). Improving the quality and microstructure of low fat Edam cheese made from buffaloe's milk. MSc. Thesis, Cairo University, Egypt.

Kosikowski, F. V. (1982). Cheese and Fermented Milk Foods. $2^{\text {nd }}$ ed. F. V. Kolsikowski Associates, Brooktonale, New York.

Ling, E. R. (1963). Text Book of Dairy Chemistry. Vol. 2. Practical, $3^{\text {rd }}$ ed., Chapman and Hall limited, London.
Mansour, F. M. S. (2005). Technological studies on Mozzarella cheese from Egyptian buffaloe's milk. Ph.D. Thesis, Ain-Shams University, Egypt.

Metwally, M. M. and M. M. Nasr (1989). Acceleration of cheese ripening using sodium dodecylsulphate. 1- Edam cheese. Agricultural Research Review, 67: 193-198.

Nasr, M. M. and M. M. K. Metwally (1989). Acceleration of cheese ripening using sodium dodecylsulphate. 2- Romi cheese. Agricultural Research Review, 67: 199-204

Niro, S., A. Fratiani, P. Tremonte, E. Sorrentino, L. Tipaldi, G. Gianfranco Panfili and R. Coppola (2014). Innovative Caciocavallo cheeses made from a mixture of cow milk with ewe or goat milk. Journal of Dairy Science, 97: 1296-1304.

Pappas, C. P., E. Kondly, L. P. Voustsinas and H. Mallatou (1996). Effect of starter level, draining time and aging on the physicochemical, organoleptic and rheological properties of Feta cheese. Journal of the Society of Dairy Technology, 49: $73-78$.

Santa, D. and S. Srbinovska (2014). Traditional production and main characteristics of Galichki Kashkaval. Mljekarstvo, 64: 119126.

Simov, Zh. I. and G. Y. Ivanov (2005). Proteolytic activity of Lacctobacillus delbrueckii ssp. Bulgaricus and Streptococcus thermophilus in frozen-stored kashkaval cheese. Journal of Industrial Microbiology \& Biotechnology, 32: 449-454.

Succi, M., M. Aponte, P. Tremonte, S. Niro and E. Sorrentino (2016). Variability in chemical and microbiological profiles of long-ripened Caciocavallo cheeses. Journal of Dairy Science, 99: 9521-9533.

Szczesniak, A. S., M. A. Brandt and H. H. Freidman (1963). Development of Standard rating Scales for Mechanical Parameters and Correlation Between the Objective and the Sensory Methods of Texture Evaluation. Journal of Food Science, 28:397- 403

Talevski, G., S. Srbinovska, D. Santa and N. Mateva (2017). Influence of packaging materials on Kashkaval quality. Mljekarstvo, 67: 25-32.

Tunick, M. H. (1999). Symposium: Dairy Products Rheology: Rheology of Dairy Foods that Gel, Stretch, and Fracture. Journal of Dairy Science, 83: 1892-1898.

Vujicic, I. F., M. Skrinjar and M. Vulic (1996). Role of protease from Penicillium roqueforti in the modification of cheese slurry and Trappist cheese ripening. Acta Alimintaria, 25: 15-25.

Wallace, J. M. and P. F. Fox (1997). Effect of adding free amino acids to Cheddar cheese curd on proteolysis, flavour and texture development. International Dairy Journal, 7: 157-167. 


\section{تأثير الأحماض الأمينية المتعادلة ودوديسيل كبريتات الصوديوم على تسوية جبن الكثكفال

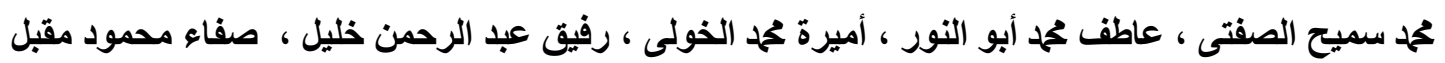

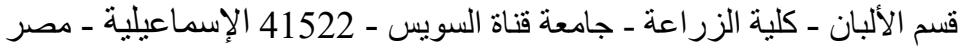

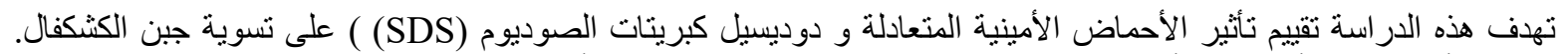

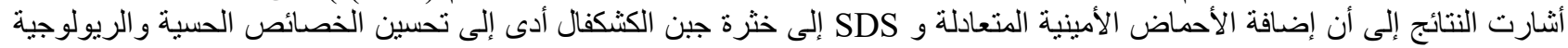

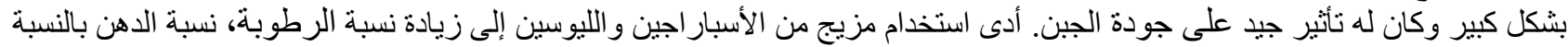

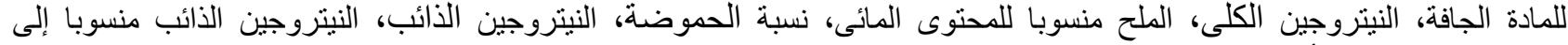

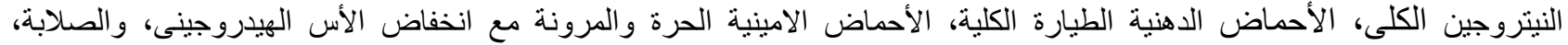

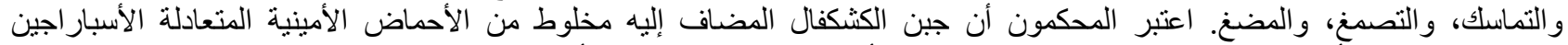
و الليوسين (1 مجم أسبار اجين + 1 مجم ليوسين/كجم خثرة) أفضل من الجبن المقارن أو معاملات الجبن المختبرة الآخرى منبوعًا بالجبن الإنين 